\title{
Performance Consequences of Mandatory Increases in Executive Stock Ownership
}

John E Core

University of Pennsylvania

David F. Larcker

Follow this and additional works at: https://repository.upenn.edu/accounting_papers

Part of the Accounting Commons

\section{Recommended Citation}

Core, J., \& Larcker, D. F. (2002). Performance Consequences of Mandatory Increases in Executive Stock Ownership. Journal of Financial Economics, 64 (3), 317-340. http://dx.doi.org/10.1016/ S0304-405X(02)00127-7

At the time of publication, John Core was pursuing a PhD from the Wharton School, University of Pennsylvania; he is now the Nanyang Technological University Professor and a Professor of Accounting at the MIT Sloan School of Management.

This paper is posted at ScholarlyCommons. https://repository.upenn.edu/accounting_papers/102

For more information, please contact repository@pobox.upenn.edu. 


\title{
Performance Consequences of Mandatory Increases in Executive Stock Ownership
}

\author{
Abstract \\ We examine a sample of firms that adopt "target ownership plans", under which managers are required to \\ own a minimum amount of stock. We find that prior to plan adoption, such firms exhibit low managerial \\ equity ownership and low stock price performance. Managerial equity ownership increases significantly in \\ the two years following plan adoption. We also observe that excess accounting returns and stock returns \\ are higher after the plan is adopted. Thus, for our sample of firms, the required increases in the level of \\ managerial equity ownership result in improvements in firm performance.

\section{Keywords} \\ managerial ownership, corporate governance, financial performance

\section{Disciplines} \\ Accounting

\section{Comments} \\ At the time of publication, John Core was pursuing a PhD from the Wharton School, University of \\ Pennsylvania; he is now the Nanyang Technological University Professor and a Professor of Accounting \\ at the MIT Sloan School of Management.
}




\title{
Performance consequences of mandatory increases in executive stock ownership ${ }^{\text {*x }}$
}

\author{
John E. Core*, David F. Larcker \\ The Wharton School, University of Pennsylvania, Philadelphia, PA 19104-6365, USA
}

\begin{abstract}
We examine a sample of firms that adopt "target ownership plans," under which managers are required to own a minimum amount of stock. We find that prior to plan adoption, such firms exhibit low managerial equity ownership and low stock price performance. Managerial equity ownership increases significantly in the two years following plan adoption. We also observe that excess accounting returns and stock returns are higher after the plan is adopted. Thus, for our sample of firms, the required increases in the level of managerial equity ownership result in improvements in firm performance.
\end{abstract}

JEL classification: G30; G32; J33; L14; L22

Keywords: Managerial ownership; Corporate governance; Financial performance

A previous version was titled "Performance Consequences of Mandatory Increases in CEO Stock Ownership." We gratefully acknowledge the helpful comments of Stanley Baiman, Wayne Guay, Paul Healy (the referee), Robert Holthausen, Christopher Ittner, and Rebecca Tsui. We thank Howard Yeh and Christine Phillips for research assistance. We gratefully acknowledge the help of John Moyer of Ernst \& Young LLP and the financial support the Wharton School.

*Corresponding author: Tel.: +1-215-898-4821; fax +1-215-573-2054.

E-mail address: jcore@wharton.upenn.edu (J.E. Core) 


\section{Introduction}

Despite the central importance of the issue to corporate finance researchers, there is no theoretical or empirical consensus on whether managerial equity ownership affects firm performance. Studies of this issue generally take one of two very different directions, as two seminal studies illustrate. On the one hand, Morck, Shleifer, and Vishny (1988) find that managers' equity ownership and firm performance is too low for many firms. On the other hand, Demsetz and Lehn (1985) predict that when firms' ownership levels are optimally determined, there will be no relation between ownership and performance.

These two schools of thought make very different assumptions about the nature of the adjustment costs of correcting suboptimal contracts. For example, Morck, Shleifer, and Vishny implicitly assume that adjustment costs are so great that firms cannot contract optimally. Therefore, some firms deliver poor performance to their shareholders. Conversely, by concentrating on the equilibrium behavior of optimizing firms, Demsetz and Lehn assume that firms can continuously recontract because there are no adjustment costs. The choice of one of these two extremes drives the design and interpretation of the results of any study that examines the relation between ownership and performance. It is perhaps not surprising that there is no consensus on the performance consequences of managerial equity ownership.

We choose an alternative, middle approach by relaxing some of the strong assumptions of this prior research. Specifically, we assume that firms choose optimal managerial equity incentives when they contract (consistent with the literature that predicts no relation between ownership and performance), but that transaction costs prohibit continuous re-contracting (consistent with the literature that documents a strong relation between ownership and performance). Because ownership is periodically 
re-optimized, we expect no association between ownership and firm performance in a cross-sectional regression that controls for the endogenous determinants of firms' optimal ownership levels. However, because contracting is not continuous, firms' ownership levels gradually deviate from the optimal level. We predict that firms that are below optimum can improve their performance by increasing ownership levels, and that a subset of these firms can benefit sufficiently from the increased performance that it is worthwhile for them to incur the recontracting costs of mandating the ownership increase. For this sample of firms, required increases in managers' ownership should strengthen firm performance.

We implement our approach by constructing a sample of firms that adopt requirements specifying the minimum amount of stock that must be held by executive officers. These contracts are generally termed "target ownership plans." Before the plan is adopted, these firms deliver low stock returns and have low levels of equity ownership. However, in the two years after the board adopts the plan, managerial stock ownership increases significantly. Finally, excess accounting returns are statistically higher in the two years following plan adoption and excess stock price returns are statistically higher in the first six months of the fiscal year in which the plan is announced. Thus, increases in managerial equity ownership from suboptimal levels appear to result in improvements in firm performance.

One advantage of our approach is that the board of directors is using the target ownership plan to mandate increased equity ownership by executives. Thus, any subsequent changes in firm performance are likely to be related to the shifts in managerial incentives brought about by increases in equity ownership. This approach differs from using a sample in which the top executives voluntarily increase ownership. If we were to use this design, we could not be sure if firm performance improved because of increased ownership or if equity ownership increased in anticipation of performance 
improvements (e.g., a form of insider trading on private information, as in Kole, 1996). Accordingly, firms adopting target ownership plans provide a unique and powerful sample for examining the link between managerial ownership and performance.

The remainder of the paper consists of five sections. Section 2 provides institutional background on target ownership plans and develops our three research hypotheses. Section 3 describes the sample selection process and provides descriptive statistics on target ownership plans. Section 4 examines the ability of variables that measure the existence of governance problems to discriminate between adopting and non-adopting firms. Section 5 describes the accounting and stock market performance consequences associated with target ownership plan adoption. A summary of the paper and concluding remarks are provided in Section 6.

\section{Institutional background and research hypotheses}

The section titled "Corporate Governance" in Campbell Soup Company's 1993 proxy statement illustrates common features of target ownership plans:

The Company is committed to shareholder-sensitive corporate governance . . . By the end of 1994, all officers (29 persons), as well as approximately 40 other executives, are required to own outright (i.e., excluding options and restricted stock) Campbell stock valued at one-half to three times base salary, depending on their positions. (Proxy statement dated October 8, 1993, p. 6)

Proxy statement disclosures of target ownership plans vary greatly in the level of detail provided. The most common plan disclosure makes an explicit formal statement of the minimum level of managerial stock ownership, where this ownership requirement must be satisfied by outright ownership of common stock (i.e., stock option holdings do not satisfy the ownership requirements). Seven percent of the plans in our sample express the target as a number of shares. The remaining plans express the target as a 
percentage of salary, so that the target becomes more difficult to attain if the stock price decreases. Finally, the typical disclosure specifies the maximum time allowed to achieve the ownership goal.

Adopting firms indicate that their motivation for imposing minimum equity ownership levels is to ensure that their managers have the appropriate incentives to increase shareholder value. For example, the 1993 proxy statement of Morrison Restaurants Inc. says:

Believing that equity ownership plays a key role in aligning the interests of Company personnel with Company stockholders, the Company encourages all employees to make a personal investment in Company stock. The Company's goal is that 10 percent of the Common Stock will be owned by employees by the year 2000 and that 80 percent of employees with more than two years of experience with the Company will own Common Stock. (Proxy statement dated August 26, 1993, p. 12)

Thus, target ownership plans are designed to address the contention of some researchers and governance activists that stock ownership of senior-level executives is "too small" (e.g., Jensen and Murphy, 1990; Jensen, 1993; Norton, 1995).

In addition to the implicit requirement created by the public announcement of the ownership targets, $52(27 \%)$ of our sample firms state an explicit penalty for executives who do not meet the ownership target. The penalty falls into one of three categories, each of which involves changing some aspect of the executive's equity compensation. When executives do not meet their targets, either (1) a fraction of their annual cash pay is paid as restricted stock, (2) their grants of options, restricted stock and cash long-term incentives are reduced or eliminated, or (3) the vesting of their outstanding restricted stock and options is delayed. Thus, by explicitly linking future equity compensation to a specific minimum ownership goal, these target ownership plans are designed to motivate executives to increase their equity ownership and to maintain this increase. 
We hypothesize that target ownership plans are adopted when the board of directors recognizes that the firm has a governance problem. The board adopts the plan in order to move the firm to a more appropriate governance structure. We assume that stock returns that are lower than industry benchmark returns are evidence of potential governance problems. The United Shareholders Association (1992) uses this approach to detect governance problems, and the approach is verified empirically by Core, Holthausen, and Larcker (1999). Another way to detect actual or potential governance problems is to determine whether a firm's managerial stock ownership is low relative to some comparison group. This approach is similar to the method used by governance monitoring groups such as Institutional Shareholder Services (1993). Thus, we predict that if a firm has low managerial stock ownership and poor stock price performance, the board infers that the level of managerial equity is insufficient to motivate good performance. One strategy for mitigating this perceived governance problem is to adopt a target ownership plan that requires managers to own a minimum level of stock. Thus, our first research hypothesis is as follows:

\section{$H_{1}$ : $\quad$ The likelihood of adopting a target ownership plan is negatively related to prior stock price performance and managerial equity ownership levels.}

We hypothesize that the board acts in the interests of shareholders to mitigate a perceived governance problem, and for that reason it adopts a "substantive" target ownership plan that mandates ownership increases by executives.

An alternative to this hypothesis is that management controls the board and convinces the board to adopt a plan that does not actually force the managers to increase their equity ownership. The purpose of this "symbolic" plan is to make it appear that managers have taken steps to improve governance, but without actually having to bear the costs of increased ownership. This hypothesis 
assumes that managers believe that outside investors are unable to discriminate between symbolic changes and substantive changes (e.g., Pfeffer, 1981).

Another explanation for an association between target ownership plan adoption and equity ownership increases is that management has private information about future firm performance and encourages the board to adopt a target ownership plan. However, if this were true, we would not expect changes in managers' relative ownership positions after plan adoption, because rational managers would take advantage of their superior information and increase their stockholdings prior to the announcement of the plan. Because managers expect to achieve the ownership targets, it will not matter to them whether the plan includes a penalty for noncompliance.

To distinguish between these competing explanations, we examine changes in managerial equity ownership following the adoption of the plan, and our second research hypothesis is as follows:

\section{$\mathrm{H}_{2}$ : $\quad$ Managerial equity ownership increases following the adoption of a target ownership plan.}

If target ownership plans improve managerial incentives, adoption should have favorable operating performance consequences for the firm. In saying this, we assume that when a firm with low ownership requires that managers increase their ownership, this increase mitigates agency problems and motivates managers to select actions that are more consistent with shareholder objectives.

The existing literature does not provide consistent evidence on the association between managerial equity ownership and firm performance. The evidence in Morck, Shleifer, and Vishny (1988) and subsequent studies suggests that equity ownership is too low at most firms, and performance will improve if managerial equity ownership increases. For example, McConnell and Servaes (1990) find evidence of a positive relation between increases in ownership and firm performance so long as managerial 
ownership is less than 50\%. Demsetz and Lehn (1985) predict, and Himmelberg, Hubbard, and Palia (1999) find, that there is no relation between equilibrium levels of ownership and firm performance. In other words, once the researcher recognizes the endogenous nature of equity ownership, there is little evidence to indicate a relation between equilibrium levels of ownership and firm performance (Himmelberg, Hubbard, and Palia).

In contrast to this prior research, we examine firms that are below equilibrium levels of managerial equity ownership. We predict that as equity ownership rises, there will be an increase in operating performance. In addition, if the stock market does not completely anticipate this contractual change, the firm's stock price will increase when the firm announces to the market that it has adopted a target ownership plan. Thus, our third research hypothesis is as follows:

$H_{3}$ : $\quad$ Adopting a target ownership plan will have a positive impact on subsequent operating and stock market performance.

\section{Sample selection and descriptive statistics on target ownership plans}

We identify our initial sample from selected articles that discuss target ownership plans (e.g., Brill, 1993; Reese, 1993; McMillan and Sabow, 1994; and Young, 1995) and from a keyword search of all proxy statements on Lexis. We read the proxy statement of each firm in the initial sample to determine whether the firm has actually adopted a target ownership plan, and we check each firm's prior year's proxy statement to ensure that we have the proxy that first announces the plan. The earliest target ownership plan adopters have December 31, 1991 fiscal year-ends. We include plan adopters with fiscal years ending up to and including December 31, 1995. Approximately $1.5 \%$ of the sample firms have 1991 fiscal year-ends, 16.9\% have 1992 FYEs, 35.5\% have 1993 FYEs, 36.9\% have 1994 FYEs, and 9.2\% have 1995 FYEs. Table 1 describes the final sample, which comprises 195 firms 
across 40 different industrial and service sectors of the economy. There is some concentration in the chemical, machinery, utilities, banking, and insurance industries.

We measure variables relative to the fiscal year in which the proxy statement announcing the plan adoption appears. Fig. 1 provides a timeline and illustration. Proxy statements appear a few months after the fiscal year-end. For example, a firm with a December 1993 fiscal year-end typically issues its proxy in April 1994. We denote the fiscal year in which the proxy statement appears as year 1 , and the fiscal year that the proxy describes as year 0 . The SEC requires that the year 1 proxy statement describe compensation during year 0, ownership at the end of year 0, and the actions of the compensation committee for the period following the year 0 proxy statement through the year 1 proxy statement. For example, the April 1994 proxy statement would describe compensation payments during the fiscal year ended December 31, 1993 (year 0), executive ownership as of the fiscal year-end (December 31, 1993), and the actions of the compensation committee from May 1993 (year 0) to April 1994 (year 1). It is during this period spanning the latter part of year 0 and the early part of year 1 that the board decides to adopt a plan. Eighty-two firms (42\%) do not specify when the board action to adopt the plan took place, $75(39 \%)$ state that the plan was adopted in year 0 , and $38(19 \%)$ indicate that the plan was adopted early in year 1.

Table 2 provides descriptive statistics for the target ownership plans and actual ownership levels. Recall that the plans require executives to own a target value of stock, which is expressed as a multiple of base salary. Consistent with the prior survey results in Towers Perrin (1993) and McMillan and Sabow (1994), Panel A shows that for the 138 firms disclosing a target, the minimum level of ownership for the median CEO is four times base salary, and the minimum level of ownership for other top executives is two and a half times base salary. For the nine firms that express the target as a number 
of shares, we convert the target into a salary multiple using the stock price at the end of year 0 . Similar to the survey results in Hewitt (1993) and Towers Perrin, the typical firm allows the executives approximately five years to comply with the minimum level of stock ownership.

Panel B, Table 2, presents statistics for the actual ownership multiples of the sample firms. We compute the ownership multiple (value of stock owned/salary) using the salary and shares disclosed in the proxy statement for year 0 , and the stock price at the end of year $0 .{ }^{1}$ The size of our sample of target ownership firms is slightly less than 195 because we cannot compute the ownership multiple for one CEO (two executive groups) due to insufficient proxy disclosure. To compute the ownership variable for the other (four) top executives, we use the data disclosed in the proxy statement for the (five) most highly compensated executives, and then exclude the CEO. We calculate a weighted average by summing the stock values of each executive and dividing this by their total salaries. The median CEO owns 5.6 times his or her salary in stock. The other executives own a median of 2.4 times their salary in stock. Because the distributions are skewed by some very large observations, the mean values are much higher than the medians, at 32.2 and 4.7 times salary, respectively.

The median values suggest that it is a minority of CEOs who have not already attained the target, and a minority of other executive teams that have not attained the minimum. To provide more direct evidence, we compare the actual ownership multiple to the actual plan minimum. To do these

\footnotetext{
${ }^{1}$ We use the value of stock disclosed in the year 0 proxy (rather than in the year -1 proxy) to maximize the sample size. The disadvantage of the year -1 shareholdings is that they are available for a much smaller group of firms. If we used year -1 numbers, our sample size would be reduced substantially because some sample firms are not public at that time and it is not always possible to determine ownership levels from 1991 proxies for 1992 adopters. Because ExecuComp does not have data prior to 1992 (i.e., prior to the 1992 reforms in proxy disclosure), we also would have no control firms for our 1992 adopters. Although the board does not know the year 0 shareholdings at the time of adoption, the interim ownership numbers that the board considers when it adopts the plan are probably close to the year 0 numbers. If some managers react to the plan adoption in year 0 by increasing their stockholdings, our measure of ownership at the time of adoption will be too large, and this will limit our ability to find significant differences between the adopters and non-adopters and to find significant increases after adoption.
} 
comparisons, we use the plan targets if disclosed (Panel A, Table 2), and if not disclosed we impute a target equal to the medians of 4.0 and 2.5 for the CEO and other executives, respectively. In Panel C, we show that $38 \%$ of CEOs are below minimum and that $49 \%$ of other executives (on a weighted average basis) are below minimum. Because the weighted average calculation can be distorted by one executive with very large ownership, we also examine whether each other executive meets the minimum. The results of this analysis indicate that for $81 \%$ of the firms, at least one other top executive does not meet his or her target. Accordingly, while only $38 \%$ of the firms have CEOs that do not exceed their minimums, $84 \%$ of the firms have a CEO or at least one other top executive who does not meet his or her minimum.

\section{Analysis of target ownership plan adoption}

In this section, we describe how we construct a test of Hypothesis 1, which predicts that target ownership adopters have lower pre-plan returns and ownership than a control sample. We define our measures, describe how we construct the control sample, and then describe our test.

\subsection{Measures for benchmark-adjusted returns and ownership}

We measure firm performance as the stock price return in the two years (years -2 and -1 in Fig. 1) preceding the adoption year 0 , less the median stock price performance during the same time period for the firms on the 1998 Compustat file that have the same two-digit SIC code. We label the resulting variable "prior industry-adjusted returns," and we assume that governance problems are an inverse function of prior industry-adjusted returns.

We compute our ownership benchmark by constructing a regression model comparable to that used by Demsetz and Lehn (1985). Because target ownership plans require executives to own a certain value of common stock directly (exclusive of stock options) that is a multiple of that executive's base 
salary, we examine the ownership multiple computed at year 0 as described above. ${ }^{2}$ To normalize the distribution of this highly skewed variable, we transform it by the natural logarithm and use $\log ($ stock value/salary) as the dependent variable in our ownership regression. This transformation enables us to interpret the residual as the percentage by which actual ownership deviates from expected ownership. We compute this variable for the CEO and for the other top executives.

Following Demsetz and Lehn (1985) and Baker and Hall (1998), we expect that managerial ownership will increase at a decreasing rate as firm size increases. We follow prior researchers in measuring size with the natural logarithm of the market value of equity at the end of year 0 , denoted as $\log ($ MV equity). Prior researchers such as Murphy (1999) find that executive salaries also increase at a decreasing rate as firm size increases. Because $\log$ (stock value/salary) is equal to $\log ($ stock value) $\log$ (salary), we do not predict the direction of the association between this variable and $\log (\mathrm{MV}$ equity). We expect that equity ownership will increase at a decreasing rate as monitoring costs increase.

We also follow Demsetz and Lehn in using stock return volatility as a proxy for noise that increases monitoring costs. We capture the hypothesized concave relation between increases in noise and increases in equity ownership by including the square of stock return volatility. We measure stock volatility by using the standard deviation of daily stock price returns over the six months before the fiscal year-end. Because several of our firms did not trade for all of year 0, we maximize our sample size by

\footnotetext{
${ }^{2}$ While our measure of ownership is consistent with the measure used in the target ownership plans, prior research has concentrated on either the fraction of the firm owned or the value of ownership (not deflated by base salary). In addition, arguably a better proxy for managerial equity incentives would also include the incentives provided by the managers' options (e.g., Core and Guay, 1999). If we use instead the logarithm of the value of managerial stock ownership or the logarithm of the total incentives provided by the manager's stock and option portfolio, our results are qualitatively the same as those discussed below. In particular, the adopting firms' managers have significantly lower equity incentives than the comparison group, and these incentives increase significantly in the two years following adoption.
} 
measuring daily stock volatility over the six months prior to the fiscal year-end. We predict that stock volatility will be positively associated with $\log$ (stock value/salary), and that stock volatility squared will be negatively associated with $\log$ (stock value/salary).

Similar to Smith and Watts (1992), we expect that CEO equity ownership will be greater for firms with larger investment opportunity sets. Like Smith and Watts, we use the book value of assets divided by the market value of assets as a proxy for growth opportunities, and expect that firms with greater growth opportunities will have lower book-to-market ratios. We measure the book-to-market ratio at the end of year 0 . We expect to find a negative relation between the book-to-market ratio and $\log$ (stock value/salary).

To control for industry factors and other unspecified determinants that might affect the level of equity ownership, we also include 23 industry indicator variables. To capture potential temporal differences, we include five indicator variables that correspond to the years of data collected from our sample of plan adopters and ExecuComp. The resulting benchmark model for the level of stock ownership is as follows:

$$
\begin{aligned}
& \log (\text { stock value } / \text { salary })_{\text {it }}=\beta_{0}+\beta_{1} \log (\mathrm{MV} \text { equity })_{\text {it }}+\beta_{2} \text { Stock volatility }_{\text {it }}+ \\
& \beta_{3} \text { Stock volatility squared }_{i t}+\beta_{4}{\text { Book-to- } \text { market }_{i t}+}+ \\
& \gamma_{1 \ldots .} \text { year indicators }{ }_{i t}+ \\
& \delta_{1 \ldots 23} \text { industry indicators } s_{\mathrm{it}}+\varepsilon_{\mathrm{it}} \text {. }
\end{aligned}
$$

We estimate this benchmark model using ordinary least squares. We create an estimation sample by pooling annual ownership data for the target ownership plan adopters for years 0,1 , and 2 with ExecuComp data on managerial ownership for firm-years from 1992 to 1997. Because ExecuComp has no 1991 fiscal year data, we include the 1991 adopters coded with a year indicator of 1992. The ExecuComp database meets our requirement for an accurate, convenient data source for managerial 
equity ownership. We include data for the years 1996 and 1997 so that we can use these residuals in later tests (described in Section 5.1) of whether the managerial equity ownership of the 1994 and 1995 plan adopters increases in the two years following adoption. To mitigate the influence of outliers, we set the upper- and lower-most percentiles for each variable equal to the values at the first and $99^{\text {th }}$ percentiles in each year, respectively.

Table 3 presents the estimation results, which indicate that the models for the CEO and other top executives are statistically significant ( $p<0.001$ ), with adjusted $R^{2} \mathrm{~s}$ of $19.4 \%$ and $17.9 \%$, respectively. All of the reported statistical tests are two-tailed. The log of the ownership multiple has a statistically positive relation to firm size. As we expected, we find a negative relation to the book-to-market ratio (or a positive relation to the investment opportunities confronting the firm). We also observe that the log of the ownership multiple has a concave relation to the standard deviation of stock returns. We find less managerial ownership for those firms with very low or very high stock volatility. We label the residual from the benchmark model the "stock value residual," and we assume that governance problems are an inverse function of the stock value residual.

\subsection{Results}

Because Hypothesis 1 predicts differences between adopting and non-adopting firms, we require a set of control firms that have not adopted a target ownership plan. We create a control sample by deleting from the sample described above all data for 1996 and 1997 and all firms that are included in our sample of target ownership plan adopters. (Because we have the full sample of target ownership adopters prior to 1996 , we know that none of our control firms have adopted plans.) A total of 4,498 firm-years on ExecuComp from 1992 to 1995 constitute our control sample. Because some firms are missing data on prior industry-adjusted returns, the target ownership sample reduces to 170 
observations and the control sample to 4,022 observations. Again, to mitigate the influence of outliers, we set the upper- and lower-most percentiles for each independent variable equal to the values at the first and $99^{\text {th }}$ percentiles in each year, respectively.

Univariate results are consistent with Hypothesis 1. We find that prior industry-adjusted returns for the target ownership plan sample are significantly lower than those for the control sample by a mean of 4.5 percentage points $(\mathrm{p}<0.002)$ and median of 0.7 percentage points $(\mathrm{p}<0.05) .{ }^{3}$ In addition, the CEO stock value residual for the target ownership plan sample is statistically lower than that of the control sample by a mean of $36.0 \%(\mathrm{p}<0.002)$ and median of $32.9 \%(\mathrm{p}<0.001)$ level. ${ }^{4}$ Finally, the other executives' stock value residual for the target ownership plan sample is statistically lower than that of the control sample by a mean of $34.2 \%(\mathrm{p}<0.002)$ and median of $35.0 \%(\mathrm{p}<0.002)$ level.

Using "Plan" as an indicator variable equal to one if a firm adopts a target ownership plan, and zero otherwise, we can express the adoption decision as follows:

$$
\begin{aligned}
\text { PLAN }_{\mathrm{it}}= & \beta_{0}+\beta_{1} \text { Prior industry-adjusted returns }_{\mathrm{it}}+\beta_{2} \text { Stock value residual }_{\mathrm{it}} \\
& +\gamma_{1 \ldots 3} \text { year indicators } \\
\mathrm{it} & +\mathrm{u}_{\mathrm{it}}
\end{aligned}
$$

where we hypothesize that $\beta_{1}<0$ and $\beta_{2}<0$.

We estimate this model using logistic regression and present the results in Table 4. In Columns 1 and 2, we see that the individual coefficient estimates (and changes in predicted probability) for prior industry-adjusted returns and the stock value residual are statistically negative at conventional levels. The changes in predicted probability for prior industry-adjusted returns indicate that if prior industry-

\footnotetext{
${ }^{3}$ A "percentage point" difference is the difference in two returns, e.g., a $1 \%$ return is 1 percentage point lower than a $2 \%$ return.

4 As noted above, because our dependent variable is $\log$ (stock value/salary), we can interpret the residual as the percentage by which actual ownership deviates from expected ownership. Further, we can interpret the differences in two residuals as percentage differences, e.g., we term the difference in the -0.336 mean residual for the adopters and the 0.026 mean residual for the control samples as a $36.2 \%$ difference.
} 
adjusted returns increase from the first quartile to third quartile and the other independent variables remain at their mean values, the predicted probability of the firm having a target ownership plan decreases from $3.8 \%$ to $3.0 \%$. Although this decrease seems small, it is arguably more relevant that it represents a relative decline of $21 \%$ in the predicted probability (DeAngelo, DeAngelo, and Skinner, 2000, p. 341). The decreases in predicted probability for CEO stock residual (Column 1) and for other executives' stock residual (Column 2) represent relative declines of $16 \%$ and $18 \%$, respectively, in the predicted probability of a target ownership plan.

When we include both the CEO and the other executives' stock value residuals in the same model (Column 3), the coefficient on the other executives' stock residual is significant $(\mathrm{p}<0.10)$, but the coefficient on the CEO stock residual is insignificant. This evidence suggests that low ownership by executives other than the CEO is a more important determinant of the decision to adopt than is low ownership by the CEO. We note that there is a 0.39 correlation between the two residuals, and that we also obtain a significant coefficient $(\mathrm{p}<0.01)$ if we instead include as a single variable a weighted average of the two residuals, in which the CEO (other executives) residual receives a 20\% (80\%) weight. If we impute a zero value for missing values of prior industry-adjusted returns (and include an indicator variable equal to one when prior industry-adjusted returns are missing), the Table 4 results are robust to this change in specification and increase in sample size. The only qualitative change is that the coefficient on the other executives' stock value residual becomes more significant in Column 3 (p < $0.01)$.

Although not reported, we also obtain qualitatively similar results if we select the control sample by using a random match that approximates the proportion of target ownership adoptions per year. For example, because $26.3 \%$ of the adoptions occur in the Compustat data year 1993, we randomly select 
26.3\% of all firms on the 1993 ExecuComp file as a control group for the 1993 adoption group, and so forth. Finally, our results are robust to our inclusion of firm size and industry indicators as additional control variables.

Thus, consistent with Hypothesis 1, our results suggest that boards respond to governance problems (as measured by low relative stock price returns and low relative managerial equity ownership) by adopting target ownership plans for senior-level executives.

\section{Consequences of target ownership plan adoption}

The majority of this section discusses how we conduct tests of our hypothesis that performance improves for target ownership plan adopters. However, before we examine the performance consequences of plan adoption, we must first determine if target ownership plans actually cause executives to increase their level of stock holdings, as we predict in our second hypotheses. If we do not find that managerial equity ownership increases after the adoption of target ownership plans, we would not expect to find improvements in performance associated with the plans.

\subsection{Changes in managerial stock ownership}

To test whether equity ownership increases following adoption, we use the stock value residuals described in Section 4.1. We examine the difference between the year 2 residual and the year 0 residual, and test whether this difference indicates a significant increase. For the sample of firms for which we can obtain proxy statement data on CEO ownership two years after plan adoption $(\mathrm{n}=174)$, we observe that the CEO stock value residual increases by a mean (median) of $14.1 \%(27.5 \%)$. The mean is marginally significant $(\mathrm{p}=0.13$ ), and the median is significant at a 0.001 level. For those firms with data on top executive ownership changes for the two years after the plan adoption $(n=173)$, we 
find that the other executives' stock value residual increases by a mean (median) of $18.2 \%(11.7 \%)$, which is statistically significant at a $0.07(0.01)$ level.

There are three possible limitations to these results. First, the increases that we document above might reflect mean reversion in executive ownership, in which case one would expect to observe increases for a sample of firms known to have a low level of ownership relative to the population. In fact, when we regress the change in ownership for the full sample on the beginning residual, we find a negative and significant coefficient on the beginning residual, which means that firms with lower ownership experience greater subsequent increases. We address this limitation by matching each sample firm to the control firm with the closest ownership residual in the adoption year. We choose from among those control firms for which we can obtain proxy statement data on ownership two years after the plan adoption. We then compute the two-year change in the stock value residual for each sample firm and compare it to the two-year change in the stock value residual for the matched control firm.

Benchmarking sample firm increases against control firm increases also addresses a second limitation, which is that managers' equity ownership is likely to increase with the time they have spent at the firm. This increase over time can occur either because of mechanical reasons related to the accumulation of stock through stock compensation plans (i.e., the exercise of stock options) or because of economic reasons, such as the need to prevent horizon problems with CEOs near retirement. Palia (1998) and Core and Guay (1999) find evidence that CEO ownership increases with the CEO's tenure.

We find that the sample firm increases are significantly greater than those of the control firms. Paired t-test (z-tests) indicate that the sample firm mean (median) increase of $14.1 \%(27.5 \%)$ in the CEO stock value residual is significantly greater than the control firm mean (median) increase of $-9.3 \%$ $(1.7 \%)$ at a $0.04(0.02)$ level. The sample firm mean (median) increase of $18.2 \%(11.7 \%)$ in the other 
executives' stock value residual is also greater than the control firm mean (median) increase of $-12.0 \%$ $(-3.9 \%)$ at a $0.02(0.02)$ level.

As a second means of controlling for CEO ownership increases over time, we add CEO tenure as an additional control variable in the regression model for $\log (\mathrm{CEO}$ stock value/salary) described by Eq. (1). We denote the residual from this model as CEO stock value residual $\mathrm{t}_{\text {tenure. }}$ Data on tenure for the other executives are not available from most firms' proxy disclosures. Therefore, we cannot control for tenure in the ownership model for the other executives. For the sample firms, we observe that the mean (median) CEO stock value residual ${ }_{\text {tenure }}$ increase of $12.4 \%(5.0 \%)$ is significantly greater than zero at a 0.12 (0.09) level, and also significantly greater than the control firm mean (median) change of $-15.8 \%$ ($12.1 \%)$ at a $0.004(0.001)$ level.

Another limitation on our results is that the changes in CEO ownership from year 0 to year 2 might be contaminated if a sample firm changes CEO during year 1 or year 2 . We delete the 42 firms with CEO turnover, and examine separately the sample of firms with the same CEO from the year of adoption until at least two years after the plan adoption $(n=132)$. For these firms, we observe that the CEO stock value residual increases by a mean (median) of 39.9\% (30.3\%), which is statistically different from zero at a $\mathrm{p}<0.01$ level. This increase is also greater than the $12.2 \%(12.0 \%)$ increase of the control firms with the same CEO at a $p<0.01$ level. ${ }^{5}$ Moreover, the ownership residuals for these CEOs are no longer statistically different from zero, indicating that these CEOs' ownership levels have increased to equilibrium levels. We obtain qualitatively the same results if we examine CEO stock value residual $_{\text {tenure }}$ instead. The sample firms' mean (median) increase of $15.6 \%(3.2 \%)$ is significantly greater

\footnotetext{
${ }^{5}$ The other executives' stock value residual for the 130 of these observations with available data increased by a mean (median) of $16.5 \%(14.2 \%)$, which is significantly greater than both zero and the $-19.9 \%(-5.6 \%)$ change for the control
} 
than both zero and the control firms' mean (median) increase of $-10.1 \%(-10.1 \%)$, and the year 2 ownership residuals for these CEOs are not statistically different from zero.

This consistent evidence of ownership increases for the CEO and for the other top executives supports Hypothesis 2 that target ownership plans are followed by significant increases in managers' equity ownership.

\subsection{Post-adoption operating performance: methodology and results}

To examine whether plan adoption improves firm performance, we first look at whether the accounting return on assets (ROA) is statistically positive over the two years (years 1 and 2) following the adoption of the target ownership plan. For accounting returns, we use the industry and performance match suggested by Barber and Lyon (1996) to develop a comparison benchmark. Barber and Lyon find that this approach generates well-specified models that can test future abnormal performance for firms that "... as a group, have historically experienced especially good or poor performance" (p. 378), or whose performance "differs only slightly" from the population (p. 396). Using this benchmark is important, because in the two years prior to adoption, our sample firms underperform the control firms' ROA by a mean of 0.9 percentage points $(\mathrm{p}<0.01)$ and median of 0.7 percentage points $(\mathrm{p}<0.01)$. Also, by examining the future performance of historical poor performers that are less likely to survive for two future years, this matching procedure mitigates any potential sample selection bias.

To implement this procedure, we select a comparison firm for each adopting firm. We match firms on their two-digit standard industrial classification (SIC) codes, and then select that firm with an ROA closest to the sample firm in the year prior to adoption. We require that the control firm's ROA be within $90 \%$ and $110 \%$ of the sample firm's ROA. We are unable to match five adopting firms

\footnotetext{
sample.
} 
because they have no Compustat data for year 0 .

Sometimes, either the sample firm or a control firm is missing data in year 1 or year 2, either because it was acquired or for some other reason. All of the 190 sample firms with year 0 data also have data available for year 1 , but nine of the firms have no data available for year 2 , so we do not compute the excess ROA for these firms. If a matching firm has no data available for either year 1 or year 2, we use the firm that is in the same SIC code with the ROA next closest to the sample firm in the year of adoption. We still require that the control firm ROA be within $90 \%$ and $110 \%$ of the sample firm ROA. When we cannot find a matching firm in the same industry, we follow Barber and Lyon (1996) and select the firm with the closest ROA regardless of its SIC code. As discussed below, Vijh (1997) uses a similar splicing method when he computes excess stock returns.

Although Barber and Lyon (1996) base their ROA calculation on operating income before depreciation expense (Compustat data item 13), this data item is not available on Compustat for certain financial institutions. To maximize our sample size, we also compute an ROA using operating income before depreciation expense (Compustat data item 178).

Table 5, Panel A, presents the accounting performance comparisons. The first line of each half of the panel indicates that our matching procedure is successful in creating a control sample whose prior-year performance is insignificantly different from that of our test sample. In the first year after the contractual change and for the cumulated two years after adoption, the target ownership sample has an ROA that is significantly greater than the control firms. The adopting firms statistically outperform the ROA (after depreciation) of the benchmark firms by a mean (median) of $1.2(0.5)$ percentage points. In the two years after adoption, the adopting firms statistically outperform the compounded ROA of the benchmark firms by a mean (median) of $1.8(0.8)$ percentage points. 
The bottom half of Panel A shows that our results are also robust for a reduced sample for which we use ROA before depreciation. Again, the adopting firms statistically outperform the ROA of the benchmark firms by a mean (median) of $1.2(0.6)$ percentage points. In the two years after adoption, the adopting firms statistically outperform the compounded ROA of the benchmark firms by a mean (median) of $1.4(0.7)$ percentage points. These results are consistent with Hypothesis 3 that target ownership plans are followed by significant increases in operating performance.

\subsection{Post-adoption stock performance: methodology and results}

We assess stock price performance in the announcement window around the release of the proxy statement and for the six-, 12-, and 24-month periods beginning in year 1, the year after target ownership plan adoption. We first examine stock market returns in the three-day window surrounding the date of the proxy statement in which the target ownership plan is disclosed. ${ }^{6}$ Using standard event study methodology (e.g., Brickley, 1986) and the statistical tests described in Patell (1976), we find that over the three-day window, the cumulative average excess return for the adopting firms is $0.15 \%$, which is statistically indistinguishable from zero $(\mathrm{p}>0.10)$. These short-window results do not support Hypothesis 3.

Although target ownership plans lead to improvements in operating performance, we might not see excess stock returns in the short time period around the proxy date. There are two reasons for this. First, although our searches of the Dow Jones and PR newswires reveal no public discussion of the plans prior to the proxy date, managers might have privately communicated the news of the adoption of a target ownership plan to large shareholders. Thus, by the proxy date, the expected benefits of the

\footnotetext{
${ }^{6}$ There is some debate on the desirability of using proxy statement release dates for detecting the shareholder value consequences associated with changes in compensation contracts; Gaver, Gaver, and Battistel (1992) discuss this
} 
plan might already be impounded into the stock price. ${ }^{7}$

Second, even if the market knows that the plan exists, target ownership plans represent an innovation, and the positive or negative performance consequences of this innovation become clear only with the passage of time. In this case, when there are improvements in operating performance, the market will be surprised and there will be positive abnormal returns for a period following the plan adoption. For example, the stock market might react to changes in managerial investment and financing decisions, rather than to the contractual change disclosed in the proxy statement. We explore these possibilities by assessing whether stock price returns are statistically positive over the six-, 12-, and 24-month periods starting in the year after target ownership plan adoption (year 1).

Barber and Lyon (1997) and Lyon, Barber, and Tsai (1999) show that the use of a control firm matched on size and book-to-market in computing buy-and-hold excess returns (BHERs) for each sample produces test statistics that are well specified in random samples of firms and for almost all nonrandom samples of firms. We use their methodology to develop our group of control firms. We obtain the matching firms from the list of all Center for Research in Securities Prices firms with price data as of the end of June of year 0 (where year 0 is the year of target ownership plan adoption). We compute market value in June of year 0 , and the book-to-market ratio by using the last book value reported prior to June of year 0 . Using the subset of firms whose market value lies between $70 \%$ and $130 \%$ of the sample firm value, we pair each sample firm with the firm that has the closest book-to-

point.

${ }^{7}$ As noted above, most of the target ownership plans are adopted in year 0 , which raises the possibility that the leakage could have occurred prior to the start of our event window at the beginning of year 1 . To address this possibility, we examine excess returns for the six months ending with the start of year 1 for the set of firms (with available return data) that do not state that they adopted early in year 0 . We find no significant excess returns for either the sample of 73 firms that specifically disclose that they adopted in year 0 , or for the 152 -firm subsample that does not state that they adopted in year 1. This finding is consistent with the lack of disclosure of the plans and with the 
market ratio. (We note that our control group is closely matched to our test sample: on average the percentage difference in firm size is $4.0 \%$ and the percentage difference in the book-to-market ratio is 0.0\%.) We compute the BHERs starting the first month of year 1, the fiscal year in which the firm releases the proxy statement announcement of the plan. Because the proxy is always released within the first six months of the fiscal year-end, all of our BHER measures can capture any announcement effects related to the plan adoption.

If either a sample or a control firm stops trading because it was acquired (or for some other reason) before the end of our accumulation period, we follow Vijh (1997) by ending the excess return calculation with the delisting month. If a control firm delists, we use the return for a firm that has the book-to-market ratio next closest to the sample firm in the year prior to adoption and a firm size within $70 \%$ and $130 \%$ of the sample firm size.

Table 5, Panel B, presents the stock price performance results. The sample firms statistically outperform the control group for the first six months of the fiscal year of adoption with a mean (median) BHER of $3.8 \%(2.9 \%)$. Although the BHERs for the 12- and 24-month periods are positive, they are insignificant at conventional levels. Combined with our findings of significant and positive operating performance, the BHER results suggest that the market reacts favorably to the adoption of the target ownership plan, and prices its expected benefits in the six-month period around plan adoption. These stock price results support Hypothesis 3.

conjecture that the board action to adopt these plans occurs late in year 0 . 


\subsection{Sensitivity analysis}

Our sample comprises firms with relatively low levels of management stock ownership prior to the adoption of the new program. However, 70 of the firms have CEOs with positive stock value residuals, 70 of the firms have other top executives with positive stock value residuals, and 38 of the firms have both CEOs and other executives with positive stock value residuals. This observation raises two issues. First, we wish to establish that our results are not driven by observations that already have appropriate equity incentives (for which we expect the incentive effects of establishing minimum ownership levels would be lower). A second issue is that if an executive has a positive stock value residual, the plan could create perverse incentives by forcing him or her to own "too much" stock.

We address the first issue in two ways. First, we delete the 38 firms that have positive stock value residuals for both the $\mathrm{CEO}$ and the other executives as a group. We then examine the performance of the remaining 157 firms and find that these firms experience large, significant increases in ownership for both the CEO and the other executives as a group in the two years after plan adoption. For this subsample, all means and medians of the excess performance variables remain positive and significant, with two exceptions. First, while excess ROA using operating income after depreciation remains significant, excess ROA using operating income before depreciation loses significance (this variable is available for fewer observations). Second, the mean excess stock return for the first six months becomes insignificant $(\mathrm{p}=0.152)$, although the median remains significant $(\mathrm{p}=0.056)$. Thus, our results are robust to deleting the subset of firms with positive stock value residuals.

Second, the plan may not require an increase in ownership even if the ownership residuals are negative (i.e., the plan is not binding). If the plan is not binding on the top executives, one might expect the incentive effects of establishing minimum ownership levels to be lower. To address this issue, we 
delete from the sample of 157 firms with negative residuals the 15 (42) firms for which the plan does not bind on at least the CEO or one of the other top executives (the CEO or the other top executives as a group), resulting in a subsample of 142 (115 firms). The inference for the subsample of 142 firms is the same as that reported above for the 157-firm subsample: all of the excess performance variables remain positive and the same variables are significant. For the smaller 115-firm subsample for which the plan is binding on the CEO or the top executives as a group, the inference is qualitatively similar to that reported above for the 157-firm subsample: all of the excess performance variables remain positive, and the same variables are significant except that the mean excess two-year ROA using operating income after depreciation becomes insignificant $(\mathrm{p}=0.141)$, although the median remains significant $(\mathrm{p}=$ 0.014). Thus, with the exception that excess ROA using operating income before depreciation loses significance in these subsamples, our results are robust to examining the subsamples of firms obtained by deleting firms with nonpositive stock value residuals and then by deleting firms without binding plans.

The finding that a subset of firms has positive ownership residuals raises another question. If a firm's executives already own a large amount of stock prior to the target ownership plan adoption, the plan could force the executives to own "too much" stock, which could create perverse incentives and lead to lower firm performance. Although this is a possibility, target ownership plans impose a floor on executive ownership levels, and do not require increases in ownership levels for executives whose holdings are already above this floor. Of the 70 sample firms with positive CEO stock value residuals, none of the firms' ownership targets require increases in ownership by the CEO. Similarly, of the 70 sample firms with positive other executive stock value residuals, none of the firms' ownership targets require increases by all of the other executives. However, eight of the targets require increases in ownership by some of the other executives. Finally, the actual increases in ownership for these firms 
either are significantly less than zero or are not different from zero, depending on the measure used for the analysis. Thus, it appears that the design of these target ownership plans does not impose excess ownership on the executives. Moreover, we find no evidence that firms with CEOs or other executives with positive stock value residuals have excess operating or stock price performance that is significantly lower than the remainder of the sample.

Finally, we note the results of two additional sensitivity tests. The two-year CEO turnover rate of $24.1 \%$ for the target ownership adopters is greater than the turnover rate of the control sample of $19 \%$, and the difference is marginally significant ( $\mathrm{p}=0.12$ from a binomial test of differences). Our accounting and stock price performance results are qualitatively the same as in Table 5 if we examine only those firms with the same CEO over the time period used for developing the performance tests. Finally, we note that we have a concentration of financial firms in our sample (as shown in Table 1), and these firms have different accounting conventions and operate in a very specific industrial sector. We obtain qualitatively the same performance results if we delete the 36 financial firms and examine separately the non-financial adopting firms; the only difference is that the six-month excess return is only marginally significant $(\mathrm{p}<0.15)$.

\section{Summary and conclusion}

We construct a powerful test of the hypothesis that re-contracting to require managers to increase equity ownership from suboptimal levels will improve incentives and increase performance. We implement this test by examining a sample of firms that adopt minimum ownership levels for executive officers. Because most managers in our sample have low ownership, these plans generally require increases in managerial ownership. We find that firms that adopt target ownership plans show lower stock price performance than do their industry peers in the time period prior to plan adoption. These 
firms also have managers who own lower levels of equity relative to our benchmark model, which is similar to that of Demsetz and Lehn (1985). We also find that managers increase their stock ownership following the adoption of a target ownership plan. These results indicate that target ownership plan adoption is an intervention by the board of directors to improve incentives and governance.

More important, we find that excess accounting returns are statistically higher in the two years following plan adoption, and that excess stock price returns are statistically higher in the first six months of the fiscal year in which the plan is announced. These results illustrate that when managers with below-equilibrium equity ownership are required to increase their ownership levels, there are improvements in firm performance.

We contribute to the literature on ownership and performance by suggesting a way to reconcile the starkly contrasting predictions and findings of Morck, Shleifer, and Vishny (1988) and Demsetz and Lehn (1985). Like Demsetz and Lehn, we assume that firms optimize ownership levels when they contract, and that at the optimum there is no association between ownership and firm performance. Like Morck, Shleifer, and Vishny, we expect that some firms are below optimum and that their performance can be improved by increasing ownership levels. Consistent with our approach, we find that mandatory increases in suboptimal equity ownership are associated with increases in subsequent firm performance. 


\section{References}

Baker, G., Hall, B., 1998. CEO incentives and firm size, NBER Working paper 6868.

Barber, B., Lyon, J., 1996. Detecting abnormal operating performance: the empirical power and specification of test statistics, Journal of Financial Economics 41, 359-399.

Barber, B, Lyon, J., 1997. Detecting long-run stock returns: the empirical power and specification of test statistics, Journal of Financial Economics 43, 341-372.

Brickley, J., 1986. Interpreting common stock returns around proxy statement disclosures and annual shareholder meetings, Journal of Financial and Quantitative Analysis 21, 343349.

Brill, J., 1993. Stock ownership guidelines for executives, The Corporate Executive (MarchApril), 381-385.

Core, J., Guay, W., 1999. The use of equity grants to manage optimal equity incentive levels, Journal of Accounting and Economics 28, 151-184.

Core, J., Holthausen, R., Larcker, D., 1999. Corporate governance, CEO compensation, and firm performance, Journal of Financial Economics 51, 371-406.

DeAngelo, H., DeAngelo, L., Skinner, D., 2000. Special dividends and the evolution of dividend signaling, Journal of Financial Economics 57, 309-354.

Demsetz, H., Lehn, K., 1985. The structure of corporate ownership: causes and consequences, Journal of Political Economy 93, 1155-1177.

Gaver, J., Gaver, K., Battistel, G., 1992. The stock market reaction to performance plan adoption, The Accounting Review 67, 172-182.

Hewitt Associates, 1993. Survey findings: executive stock ownership guidelines, Lincolnshire, Ill: Hewitt Associates.

Himmelberg, C., Hubbard, G., Palia, D., 1999. Understanding the determinants of managerial ownership and the link between ownership and performance, Journal of Financial Economics 53, 353-384.

Institutional Shareholder Services, 1993. The ISS Proxy Voting Manual, Washington, D.C.: Institutional Shareholder Services. 
Jensen, M., 1993. The modern industrial revolution, exit, and the failure of internal control systems, Journal of Finance 48, 831-880.

Jensen, M., Murphy, K. 1990. Performance pay and top-management incentives, Journal of Political Economy 98, 225-264.

Kole, S., 1996. Managerial incentives and firm performance: incentives or rewards? Advances in Financial Economics 2, 119-149.

Lyon, J, Barber, B., Tsai, C., 1999. Improved methods for tests of long-run abnormal stock returns, Journal of Finance 54, 341-372.

McConnell, J., Servaes, H., 1990. Additional evidence on equity ownership and corporate value, Journal of Financial Economics 27, 595-612.

McMillan, J., Sabow, S., 1994. Encouraging executive stock ownership, The Corporate Board (January/February), 16-20.

Morck, R., Shleifer, A., Vishny, R., 1988. Management ownership and market valuation: an empirical analysis, Journal of Financial Economics 20, 293-315.

Murphy, K, 1999. Executive compensation, in Ed. O Ashenfelter and D. Card, Handbook of Labor Economics, Vol. 3, Amsterdam: North-Holland.

Norton, L., 1995. Velvet handcuffs, Barron's (July 24), 21-24.

Palia, D., 1998. The endogeneity of managerial compensation in firm valuation: a solution. Working paper, Columbia University.

Patell, J., 1976. Corporate forecasts of earnings per share and stock price behavior: empirical tests, Journal of Accounting Research 14, 246-276.

Pfeffer, J., 1981. Power in Organizations, Boston: Pitman.

Reese, J., 1993. Buy stock -- Or die, Fortune (August 23), 14-15.

Smith, C., Watts, R., 1992. The investment opportunity set and corporate financing, dividends and compensation policies, Journal of Financial Economics 32, 263-292.

Towers Perrin, 1993. Stocking up in the 90s: how companies are creating managers/owners, CompScan. 
United Shareholders Association, 1992. 1992 Shareholder 1,000: rating corporate America's responsiveness to shareholders.

Vijh, A.,1997. Long-term returns for equity carveouts, Journal of Financial Economics 51, 273308.

Young, L., 1995. The owner mentality, The Wall Street Journal (April 12), R12. 


\section{Table 1}

\section{Industry composition of firms adopting target ownership plans}

The sample consists of 195 firms that adopt target ownership plans. This table lists the number of sample firms in each two-digit standard industrial classification (SIC) code, and a description of that industry.

\begin{tabular}{|c|c|c|}
\hline SIC code & \# of firms & Industry Description \\
\hline 1 & 2 & Agriculture - Crops \\
\hline 10 & 1 & Mining \\
\hline 13 & 4 & Petroleum and natural gas \\
\hline 16 & 1 & Heavy construction \\
\hline 20 & 8 & Foods \\
\hline 22 & 2 & Textile \\
\hline 23 & 1 & Apparel \\
\hline 24 & 1 & Lumber \\
\hline 25 & 2 & Furniture \\
\hline 26 & 2 & Paper \\
\hline 27 & 5 & Publishing and printing \\
\hline 28 & 20 & Chemical \\
\hline 29 & 4 & Petroleum refining \\
\hline 30 & 3 & Tires and rubber \\
\hline 32 & 2 & Stone, metal, and glass \\
\hline 33 & 3 & Steel and nonferrous metals \\
\hline 34 & 1 & Metal fabricating \\
\hline 35 & 15 & Machinery \\
\hline 36 & 9 & Electrical equipment \\
\hline 37 & 9 & Automobile and aerospace equipment \\
\hline 38 & 8 & Instruments and measuring equipment \\
\hline 39 & 2 & Miscellaneous manufacturing \\
\hline 40 & 3 & Railroad \\
\hline 41 & 1 & Bus transit \\
\hline 44 & 2 & Water transportation \\
\hline 48 & 9 & Telephone and broadcast media \\
\hline 49 & 12 & Electric and gas services \\
\hline 50 & 3 & Durable wholesale \\
\hline 51 & 5 & Nondurable wholesale \\
\hline 52 & 1 & Building materials \\
\hline 53 & 3 & Retail merchandise \\
\hline 57 & 1 & Retail home furniture and equipment \\
\hline 58 & 3 & Eating and drinking places \\
\hline 60 & 16 & Commercial banking \\
\hline 61 & 6 & Credit institutions \\
\hline 63 & 14 & Insurance \\
\hline 64 & 1 & Insurance agents \\
\hline 73 & 8 & Business services \\
\hline 75 & 1 & Automobile rental \\
\hline 80 & 1 & Health services \\
\hline
\end{tabular}




\section{Table 2 \\ Descriptive Statistics}

The sample consists of 195 firms adopting target ownership plans. Panel A contains descriptive statistics for the ownership multiples (stock value divided by salary) required for the CEOs and the other top executives, and the period allowed for the executives to reach this target. Number is the number of the 195 adopters whose proxy statements provide data. Panel B gives descriptive statistics for the actual multiple for the CEO and the other top executives. For the CEO, the multiple is (value of stock owned/salary). The other executives are the most highly compensated executives as group, excluding the CEO. The multiple for the other top executives is a weighted average equal to the total value of stock owned by the other executives divided by their total salary. We compute the multiples by using the salary and shares owned as disclosed in the proxy statement for the adoption year 0 , and the stock price at the end of year 0. Panel $\mathrm{C}$ gives descriptive statistics for the number of firms for which the actual multiple for the CEO and the other top executives is less than the minimum specified by the firm. When no minimum is specified, we impute the minimum using the median values shown in Panel A.

Panel A Ownership minimums and compliance periods

Number Mean Median Min Max

\begin{tabular}{lccccc}
$\begin{array}{l}\text { Ownership minimum } \\
\text { (multiple of base salary): }\end{array}$ & & & & & \\
$\quad$ Chief executive officer (CEO) & 138 & 4.0 & 4.0 & 0.4 & 11.0 \\
Other top executives & 116 & 2.5 & 2.5 & 0.1 & 8.6 \\
Compliance period (years) & 103 & 5.0 & 5.0 & 0.0 & 10.0 \\
\hline
\end{tabular}

Panel B Actual ownership multiples

\begin{tabular}{|c|c|c|c|c|c|}
\hline Descriptive Statistic & Number & Mean & Median & Min & Max \\
\hline \multicolumn{6}{|l|}{$\begin{array}{l}\text { Actual ownership } \\
\text { (multiple of base salary): }\end{array}$} \\
\hline Chief executive officer (CEO) & 194 & 32.2 & 5.6 & 0.0 & $1,111.7$ \\
\hline Other top executives as a group & 193 & 4.7 & 2.4 & 0.1 & 55.0 \\
\hline \multirow[t]{2}{*}{ Panel C } & is less than & ninimum mı & ultiple & & \\
\hline & Number & $\begin{array}{l}\text { Number } \\
\text { below } \\
\text { minimum }\end{array}$ & \multicolumn{2}{|c|}{$\begin{array}{c}\text { Percent } \\
\text { below } \\
\text { minimum } \\
\end{array}$} & \\
\hline Chief Executive Officer (CEO) & 194 & 73 & \multicolumn{2}{|c|}{$38 \%$} & \\
\hline Other top executives as a group & 193 & 94 & \multicolumn{2}{|c|}{$49 \%$} & \\
\hline At least one other top executive & 193 & 156 & \multicolumn{2}{|c|}{$81 \%$} & \\
\hline At least one executive (including CEO) & 195 & 163 & \multicolumn{2}{|c|}{$84 \%$} & \\
\hline
\end{tabular}




\section{Table 3}

\section{OLS regression models of $\log (\text { stock value/salary })_{t}$}

This table summarizes regression results from estimating Eq. (1). The sample consists of 7,373 firm-year observations for years 1992 to 1997 for the target ownership plan adopters and for firms included on ExecuComp. We base $t$ statistics (in parentheses) on OLS standard errors. Log(CEO stock value/salary) is the natural logarithm of the value of stock owned by the CEO divided by the CEO's salary. Log(other execs' stock value/salary) is the natural logarithm of the total value of stock owned by the other executives divided by the total salary of the other executives. The other executives are the most highly compensated executives, excluding the CEO. We compute these variables by using the salary and shares owned as disclosed in the year t proxy statement, and the stock price at the end of year $\mathrm{t}$. We compute all the explanatory variables at or for the period ending at year t. Log(MV equity) is the natural logarithm of the market value of equity. Stock volatility is the standard deviation of daily stock price returns over six months. Stock volatility squared is the square of stock volatility, and book-to-market is the book value of assets divided by the market value of assets. Coefficients on an intercept, five year indicators, and 23 industry indicators are not shown.

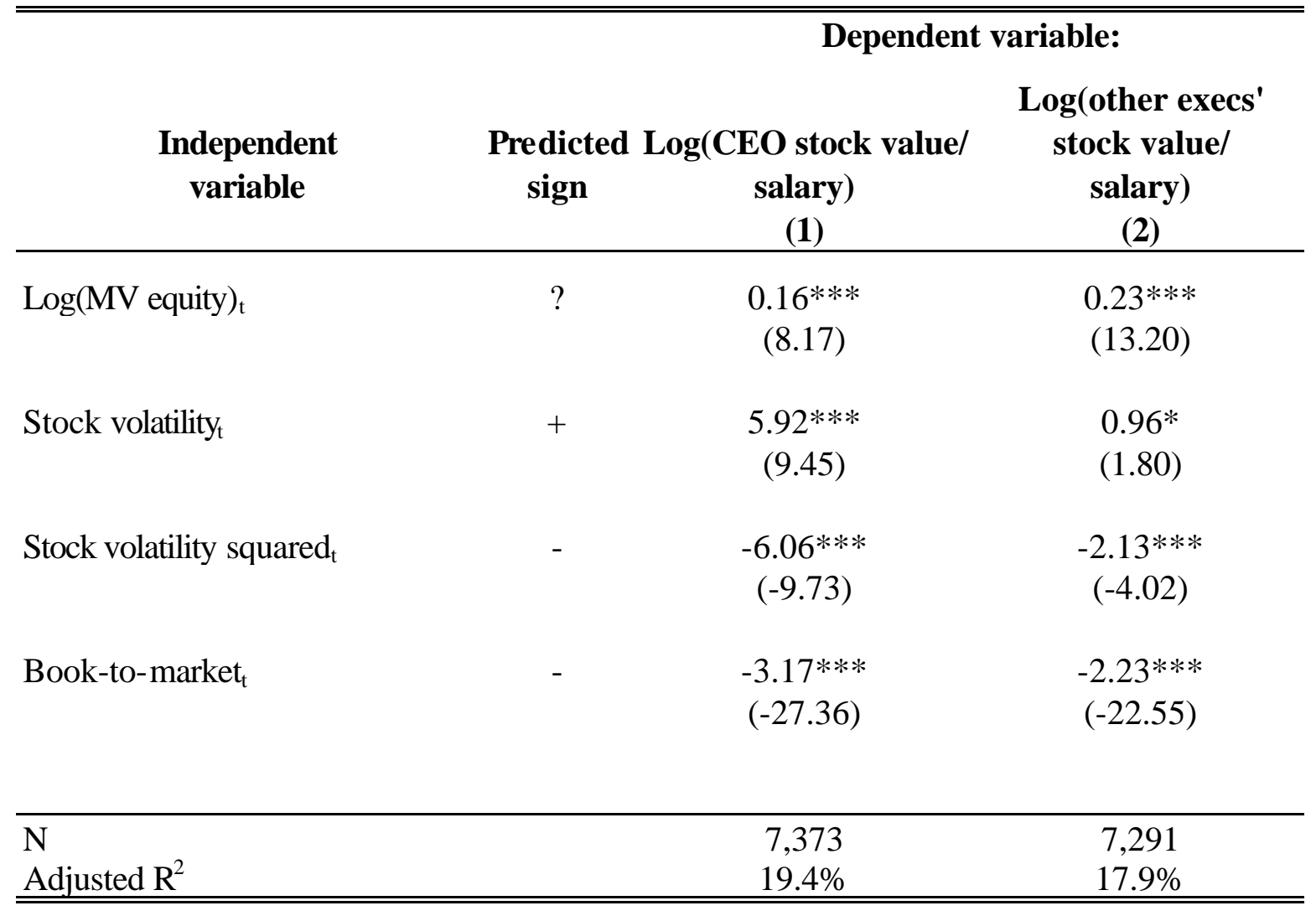

$* * *, * * *$ significant at a $0.01,0.05,0.10$ level (two-tailed). 


\section{Table 4}

\section{Determinants of the decision to adopt a target ownership plan}

This table summarizes estimation results of Eq. (2), which is a logistic model in which the dependent variable is equal to one if a firm adopts a target ownership plan and zero otherwise. The sample consists of 4,192 firm-year observations from 1992 to 1996. $\Delta$ Pred. Prob. is the change in the predicted probability that occurs when the independent variable increases from its first to third quartile value, and is evaluated at the mean values of the remaining independent variables. We base $t$-statistics (in parentheses) on maximum likelihood standard errors. The prior industryadjusted return is the stock price return in the two years preceding the fiscal year in which the plan is adopted, less the median stock price performance during the same time period for all firms contained in the 1998 Compustat file that have the same two-digit SIC code. The stock value residual is the residual obtained from estimating the model described by Eq. (1). We measure the stock value residual at the end of the year in which the plan is adopted. Coefficients on the intercept and three year indicator variables are not shown.

\begin{tabular}{|c|c|c|c|}
\hline $\begin{array}{l}\text { Independent } \\
\text { variable }\end{array}$ & $\begin{array}{c}\text { Coefficient } \\
\text { estimate } \\
\text { [DPred. Prob.] } \\
\text { (t-statistic) } \\
\text { (1) } \\
\end{array}$ & $\begin{array}{c}\text { Coefficient } \\
\text { estimate } \\
\text { [A Pred. Prob.] } \\
\text { (2) }\end{array}$ & $\begin{array}{c}\text { Coefficient } \\
\text { estimate } \\
\text { [DPred. Prob.] } \\
\text { (3) }\end{array}$ \\
\hline Prior industry-adjusted returns & $\begin{array}{c}-1.23 * * * \\
{[-0.82 \%]} \\
(-2.92)\end{array}$ & $\begin{array}{c}-1.26 * * * \\
{[-0.84 \%]} \\
(-2.98)\end{array}$ & $\begin{array}{c}-1.23 * * \\
{[-0.76 \%]} \\
(-2.88)\end{array}$ \\
\hline CEO stock value residual & $\begin{array}{c}-0.08 * * \\
{[-0.58 \%]} \\
(-2.06)\end{array}$ & & $\begin{array}{c}-0.05 \\
{[-0.34 \%]} \\
(-1.22)\end{array}$ \\
\hline $\begin{array}{l}\text { Other execs' } \\
\text { stock value residual }\end{array}$ & & $\begin{array}{c}-0.12 * * \\
{[-0.69 \%]} \\
(-2.44)\end{array}$ & $\begin{array}{c}-0.10 * \\
{[-0.51 \%]} \\
(-1.80)\end{array}$ \\
\hline $\begin{array}{l}\mathrm{N} \\
\text { \# adopting } \\
\text { \# non-adopting } \\
\text { Pseudo } \mathrm{R}^{2} \\
\text { model p-value }\end{array}$ & $\begin{array}{c}4,192 \\
170 \\
4,022 \\
4.1 \% \\
<0.0001\end{array}$ & $\begin{array}{c}4,113 \\
168 \\
3,945 \\
4.5 \% \\
<0.0001\end{array}$ & $\begin{array}{c}4,113 \\
168 \\
3,945 \\
4.6 \% \\
<0.0001\end{array}$ \\
\hline
\end{tabular}

$* * *, * *, *$ significant at a 0.01, 0.05, 0.10 level (two-tailed). 


\section{Table 5}

Two-year post-adoption excess operating and stock performance for target ownership firms

The sample consists of 190 target ownership firms. We calculate excess ROA by using the matched-firm approach of Barber and Lyon (1996), where the matching firm is the firm in the same industry with the closest prior operating performance, and by using both operating income after depreciation and operating income before depreciation. We calculate excess stock returns using the matched-firm approach of Barber and Lyon (1997), where each sample firm is matched to the non-sample firm with the closest book-to-market ratio within that subset of firms whose market value lies between $70 \%$ and $130 \%$ of the sample firm market value.

\section{A. Operating performance:}

Excess ROA computed using operating income after depreciation

\begin{tabular}{lccccc}
\hline & $\mathrm{n}$ & Mean & $\mathrm{p}$-value & Median & $\mathrm{p}$-value \\
\hline & & & & & \\
Prior year & & & & & \\
performance & 190 & $0.0 \%$ & 0.552 & $-0.0 \%$ & 0.321 \\
One year & 190 & $1.2 \%$ & 0.028 & $0.5 \%$ & 0.024 \\
Two years & 181 & $1.8 \%$ & 0.017 & $0.8 \%$ & 0.002 \\
\hline
\end{tabular}

Excess ROA computed using operating income before depreciation

\begin{tabular}{lccccc}
\hline & $\mathrm{n}$ & Mean & $\mathrm{p}$-value & Median & $\mathrm{p}$-value \\
\hline & & & & & \\
Prior year & & & & & \\
performance & 181 & $0.0 \%$ & 0.843 & $-0.0 \%$ & 0.462 \\
One year & 181 & $1.2 \%$ & 0.049 & $0.6 \%$ & 0.017 \\
Two years & 173 & $1.4 \%$ & 0.068 & $0.7 \%$ & 0.025 \\
\hline
\end{tabular}

\section{B. Stock price performance:}

Excess returns

\begin{tabular}{lcclcc}
\hline & $\mathrm{n}$ & Mean & $\mathrm{p}$-value & Median & $\mathrm{p}$-value \\
\hline & & & & & \\
Six months & 190 & $3.8 \%$ & 0.086 & $2.9 \%$ & 0.041 \\
One year & 190 & $5.7 \%$ & 0.161 & $5.7 \%$ & 0.160 \\
Two years & 190 & $5.3 \%$ & 0.442 & $7.9 \%$ & 0.171 \\
\hline
\end{tabular}


Figure 1

Timeline

\begin{tabular}{|l|c|c|c|c|} 
Year -2 & Year -1 & \multicolumn{2}{|c|}{ Year 0 } & Year 1 \\
\hline & & & $\begin{array}{c}\text { Plan } \\
\text { adoption }\end{array}$ & \\
Proxy date \\
announcing plan adoption
\end{tabular}

\section{Example:}

Suppose a firm with a December 31 fiscal year-end announces the adoption of its target ownership plan in its April 1994 proxy. Then year 0 is the year ended December 31, 1993, and year 1 is the year ended December 31, 1994.

For this example firm, in Table 3, we compute the $\log$ (stock value/salary) and the explanatory variables at December 31, 1993.

In Table 4, we measure the stock value residual at December 31, 1993. We measure the prior industryadjusted returns over years -2 and -1, or the two years ending December 31, 1992.

We measure the increase in ownership using the difference between stock value residuals at December 31, 1995 and December 31, 1993.

We measure the performance subsequent to plan adoption over years +1 and +2 , or the two years ending December 31, 1995. 